\title{
Active and Retirement Life Expectancy in Finland
}

\author{
HELKA HYTTI
}

Research Associate

The Social Insurance Institution

Helsinki, Finland

\begin{abstract}
The main purpose of the study was to examine how retirement and active life time have changed in relation to the total life expectancy in the Finnish population over the period 1970-1993. The study also aimed at finding out how the ratio between pensioners and the active population will evolve, if the general aim of Finnish pension policy, to postpone retirement, is reached. Active and retirement life expectancies were calculated by the prevalence-based Sullivan method. The data consisted of official life tables and joint statistics on the share of pension recipients in the total population of Finland. The central finding was that the increase in life expectancy had almost exclusively lengthened the time spent in retirement. Active life expectancy at birth varied relatively little. Early retirement had increasingly concentrated in the population aged 55-64, while in the middle-aged population, those under 55, active years had increased more than total years of life. Prolonging active life expectancy at birth by one year per decennium from 1990 to 2020 would reduce the increase in the pensioner population by nearly one half compared with the growth projected on the basis of 1990 prevalence rates.
\end{abstract}

Keywords: pensioners, retirement, life expectancy, Finland

\section{Background}

The population age structure of Finland has been very favorable during the last two decades, which may have influenced the way problems of the aging labor force have been solved. Early exit from gainful employment to disability and early retirement pensions has been made possible for large numbers of people. As a result, the proportion of population on disability and early retirement pensions in Finland is high by international comparison (Social tryghed i de nordiske lande 1993, 162, 168). Despite a high share of pensioners in the working-age population, the economic dependency ratio was sustainable until the crises of the 1990s, thanks to the fairly young population age structure, a high population employment ratio, and favorable economic development. The situation has, however, changed dramatically owing to the mass unemployment of the 1990 s and the expected growth in the elderly population after the turn of the century.

Population projections show that the number of pension recipients will grow by several hundred thousand from 1995 to 2020. Most of this increase will occur after 
the year 2010 when the postwar baby boom generation will begin to reach the pensionable age of 65 . One aim of the official Finnish pension policy today is that the growth of the pensioner population should be contained by postponing retirement until later in life. At the moment only $10 \%$ of the working age population reaches the pensionable age of 65 without getting a pension from any pension program (The Central Pension Security Institute and the Social Insurance Institution 1994).

The aim of postponing retirement has been explained in terms of the average retirement age. According to the Pension Committee 1990, the average retirement age in Finland should be raised by one year per decennium from 1990 to 2020 (Eläkekomitea 1990, 3). The average retirement age, measured as the average age of new pension recipients, has, however, turned out to be a problematic measure for the outcomes of the pension policy. At least in the short run, there has been no clear association between average retirement age and the inflow of new pension recipients (see Figure 1). This study is an attempt to find a better measure to monitor the effects of pension policy.

Fig u re 1. New pension recipients and the average retirement age in national pension insurance, 1970-1992.

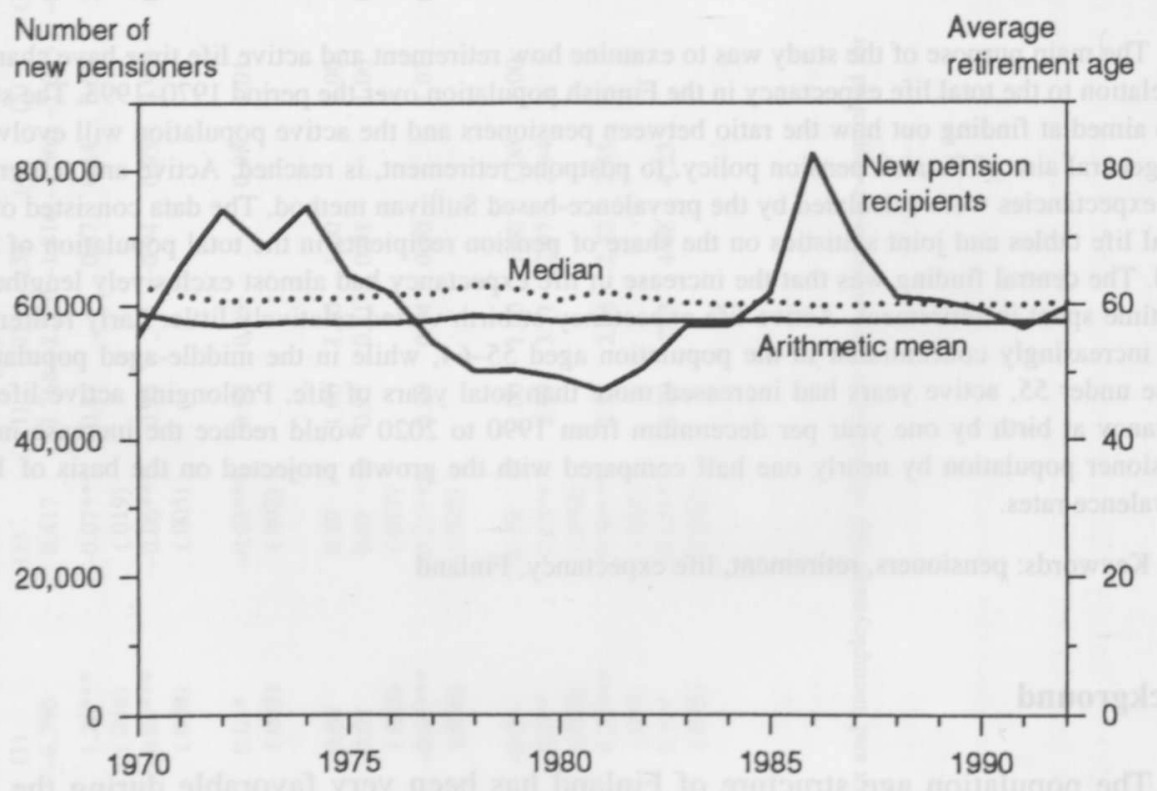

Source: Statistics of the Social Insurance Institution.

\section{Aim of the study}

The main purpose of the study was to examine in a life table perspective how retirement and active lifetime have changed relative to the total average lifetime within the last two decades. Retirement was defined as receiving a pension from at least one pension program. Active lifetime was defined as the difference between total lifetime and retirement.

The second purpose of the study was to find out the relationship between, on one hand, changes in active and retirement life expectancies, and, on the other hand, changes 
in the economic dependency ratio of the Finnish population. More specifically, only one aspect of the economic dependency ratio was examined, i.e., the ratio between pensioners and the active population. The baseline year for calculations was 1990 and projections were made until the year 2020. The question was what impact prolonging the active life expectancy by one year per decennium has on the projected number of pensioners in the years 2000-2020 and how the ratio between pensioners and the active population will evolve, if the aim of the Pension Committee 1990 is reached.

\section{Methods}

The proportioning of total life expectancy into active and retirement years can be estimated by means of two life table methods. The prevalence-based Sullivan method indicates active and retirement life expectancies on the assumption that the probability of death and the share of pension recipients in each individual age group are both fixed at the study year level throughout the lifetime of the cohort. The multistate method, based on the incidence of retirement, assumes that the likelihood of transition between active status, retirement, and death is fixed.

The two approaches have been widely used in the sociology of health to summarize information on mortality, on one hand, and morbidity and/or disability, on the other. (For discussion of the Sullivan method, see Bebbington 1988; Crimmins et al. 1989; van Ginneken et al. 1991; Valkonen et al. 1994; Sihvonen 1994; Sihvonen et al. 1994. For the multistate method, see Rogers et al. 1990; Branch et al. 1991.) According to Crimmins et al. (1993), these two methods are conceptually very different and give different answers to questions of active life expectancy. The Sullivan method indicates the actual retirement status and mortality conditions of a real population. Multistate estimates of active life expectancy are derived from a set of transitions between different states. Thus, this measure is an indicator of the implication of current risk rates for individual life cycles.

In this article, retirement and active life expectancies have been calculated by means of the Sullivan method. The calculation principles are shown in Table 1. Results derived through application of the multistate method have been discussed elsewhere (Hytti 1995). Results from the multistate method gave an active life expectancy about half a year longer than the Sullivan method after definitional differences in data sets were eliminated.

\section{Material}

The material consists of life tables for 1970-1993 compiled by Statistics Finland and two sets of - differently compiled - statistics on the share of pension recipients in the total population. For 1970, no life table specific to a single year was available; hence the life expectancy for that year has been calculated on the basis of the life table for the years 1966-1970. The data on pension recipients for 1990-1993 are based on the statistics on pension recipients in Finland published jointly by the Central Pension Security Institute and the Social Insurance Institution (The Central Pension Security Institute and the Social Insurance Institution 1991; 1993; 1994). The analysis includes all recipients of individual and special pensions. The population shares of pension recipients in 1970, 1975, 1980, and 1985 were derived from the EKSY material, which combines census data, cause of death records and pension records (Statistics Finland permission TK-53-593-94; for a discussion of the material see Hytti 1993, 56- 
T a b l e 1. Total, active and retirement life expectancy in 1993, both sexes (the prevalence-rate Sullivan method)

Total life expectancy

Retirement life expectancy

Active

$\begin{array}{ccc}\begin{array}{c}\text { Number } \\ \text { alive }\end{array} & \begin{array}{c}\text { Years } \\ \text { lived in }\end{array} & \begin{array}{c}\text { Years } \\ \text { lived }\end{array} \\ \text { at age } & \text { the age- } & \text { beyond } \\ \mathrm{x} & \text { interval } & \text { age } \mathrm{x}\end{array}$

Life Propor- Pension Pension Retire- expectexpect- tion years years ment ancy ancy of pen- lived in beyond life at age sioners the age- age $x$ expect-

$\mathrm{X}$ in age interval ancy

\begin{tabular}{lcrcccrrrr} 
Age & $(\mathrm{lx})$ & \multicolumn{1}{c}{$(\mathrm{Lx})$} & \multicolumn{1}{c}{$(\mathrm{Tx})$} & $(\mathrm{ex})$ & $\begin{array}{c}\text { (rx) } \\
\text { (Lrx) }\end{array}$ & \multicolumn{1}{c}{$($ Trx $)$} & (erx) & (eax) \\
$0-15$ & 100,000 & $1,590,879$ & $7,588,360$ & 75.88 & 0,0000 & 0 & $2,005,261$ & 20.05 & 55.83 \\
$16-19$ & 99,278 & 396,729 & $5,997,481$ & 60.41 & 0.0076 & 3,025 & $2,005,261$ & 20.20 & 40.21 \\
$20-24$ & 99,057 & 494,476 & $5,600,752$ & 56.54 & 0.0115 & 5,686 & $2,002,237$ & 20.21 & 36.33 \\
$25-29$ & 98,706 & 492,362 & $5,106,276$ & 51.73 & 0.0166 & 8,162 & $1,996,551$ & 20.23 & 31.50 \\
$30-34$ & 98,222 & 489,746 & $4,613,914$ & 46.97 & 0.0221 & 10,832 & $1,988,388$ & 20.24 & 26.73 \\
$35-39$ & 97,658 & 486,442 & $4,124,168$ & 42.23 & 0.0333 & 16,204 & $1,977,557$ & 20.25 & 21.98 \\
$40-44$ & 96,863 & 481,417 & $3,637,726$ & 37.56 & 0.0480 & 23,101 & $1,961,352$ & 20.25 & 17.31 \\
$45-49$ & 95,641 & 474,152 & $3,156,309$ & 33.00 & 0.0725 & 34,398 & $1,938,251$ & 20.27 & 12.74 \\
$50-54$ & 93,917 & 463,538 & $2,682,157$ & 28.56 & 0.1388 & 64,326 & $1,903,852$ & 20.27 & 8.29 \\
$55-59$ & 91,400 & 448,632 & $2,218,619$ & 24.27 & 0.3576 & 160,442 & $1,839,527$ & 20.13 & 4.15 \\
$60-64$ & 87,783 & 426,166 & $1,769,987$ & 20.16 & 0.7867 & 335,264 & $1,679,085$ & 19.13 & 1.04 \\
$65-$ & 82,335 & $1,343,821$ & $1,343,821$ & 16.32 & 1.0000 & $1,343,821$ & $1,343,821$ & 16.32 & 0.00
\end{tabular}

Summary of one-year age group table. Here: $x=$ lower age group boundary.

57). In the EKSY material, pension recipients were defined as those identified as pension recipients in the census as well as those registered as receiving a pension according to pension records. The comparability of the findings based on the EKSY material and those based on the joint statistics on pension recipients can be studied by consulting the two columns in Table 2, which focus on the year 1985. The two sets of findings are quite consistent, except in the oldest working-age cohort, in which the joint statistics show a slightly higher number of pension recipients than does the EKSY material.

$\mathrm{T} \mathrm{a} b \mathrm{l}$ e 2. Pension recipients as a percentage of population of working age by age group 1970-1993

$\begin{array}{lrrrrrrr}\text { Age } & \text { Year } & & & & & & \\ \text { group } & 1970 & 1975 & 1980 & 1985 \mathrm{a} & 1985 \mathrm{~b} & 1990 & 1993 \\ 16-64 & 8.6 & 11.2 & 10.6 & 11.3 & 11.2 & 12.6 & 12.5 \\ 16-19 & 1.3 & 1.2 & 1.0 & 1.0 & 0.9 & 0.8 & 0.8 \\ 20-24 & 1.6 & 1.8 & 1.5 & 1.3 & 1.3 & 1.2 & 1.2 \\ 25-29 & 1.8 & 2.0 & 2.2 & 1.9 & 1.8 & 1.7 & 1.6 \\ 30-34 & 2.5 & 2.5 & 2.5 & 2.7 & 2.6 & 2.4 & 2.2 \\ 35-39 & 3.2 & 3.6 & 3.2 & 3.2 & 3.2 & 3.5 & 3.3 \\ 40-44 & 4.6 & 5.5 & 5.0 & 4.4 & 4.6 & 4.7 & 4.8 \\ 45-49 & 7.5 & 9.5 & 8.3 & 7.4 & 7.8 & 7.6 & 7.1 \\ 50-54 & 12.0 & 17.4 & 15.1 & 13.6 & 14.0 & 14.5 & 13.7 \\ 55-59 & 20.9 & 33.6 & 34.2 & 36.8 & 36.0 & 37.5 & 35.1 \\ 60-64 & 45.4 & 61.5 & 60.3 & 66.2 & 69.0 & 77.1 & 80.4\end{array}$

Sources: EKSY material (1970-1985a); The Central Pension Security Institute and the Social Insurance Institution, 1991, 1993, 1994. 


\section{The main features of the Finnish pension system}

For the purposes of this study, the pensioner population is taken to include persons receiving a pension from at least one of the pension systems in Finland. There are two main pension insurance systems in Finland: the national pension system and the employment pension system. National pension insurance, which covers the entire population, is aimed at providing a minimum income security to all pension recipients. Employment pensions are proportional to previous earnings and are payable to employees as well as to self-employed persons. The national pension and the employment pension systems provide pensions on the grounds of old age, invalidity, and longterm unemployment. In addition, there are special grounds on which pension can be claimed. The old age, invalidity and unemployment pensions are termed individual pensions. The front-veterans pensions, the early front-veterans pensions, as well as the change-of-generations and the farm closure pensions are grouped under the heading "special pensions".

Pensionable age in Finland is 65 years. However, in the state and municipal pension systems the pensionable age is 63 or lower. In 1986-1989 a pension reform introducing flexible retirement was enforced. It became possible to draw old age pensions before the age of 65 by opting for an early old age pension, which is paid at a permanently reduced rate. The early old age pension is payable from age 60 (in the private sector) or from age 58 (in the public sector). In the same 1986-1989 reform a special invalidity pension, intended for persons between 55 and 64 with a long period of service, was introduced. The award criteria for the special invalidity pensions are less strict than those for the ordinary invalidity pension.

The legislation governing early retirement pensions has been revised several times during the study period (1970-1993). These revisions have had a major impact on the number of pension recipients in the 55-64 age group. The main changes have been the temporary lowering of the age limit (now 60 years) for unemployment pension from 1978 until 1990 and the introduction of flexible pensionable age in 1986 to 1989 (special invalidity pension, early old-age pension and part-time pension). In addition to changes in the law, the number of pensioners in the 55-64 age group has been influenced by the aging of the birth cohorts whose members served on the front in the Second World War. Towards the end of the study period, the number of pensions paid for front-line service declined rapidly as the youngest age cohorts with front-line experience reached the normal pensionable age.

\section{Results}

Changes in retirement and active life expectancy in relation to total life expectancy, 1970-1993

As can be seen in Figure 2, total life expectancy and retirement life expectancy show a nearly equal rate of increase. Active life expectancy has varied only slightly. In 1993, the total life expectancy for both sexes was 75.9 years. Of that, 55.8 years was active lifetime without a pension and 20.1 years time spent in receipt of a pension. Compared to the 1970 situation, total life expectancy had increased by 6.1 years and retirement life expectancy by 6.6 years, while active life expectancy was down by 0.5 years. The range of variation in active life expectancy during the study period is only 1.3 years. It was at its shortest in 1975 (55.2 years) and longest in the early 1970 s (56.3 years). The decline in active years in the first half of the 1970 s was due to a high general incidence of invalidity pensions and the high prevalence of front- 
veterans pensions in the oldest male age groups in the mid-1970s. In the early 1980s, active life expectancy was 56.0 years, decreasing by the beginning of the 1990 s to 55.5 years due to the growing incidence of early retirement pensions. In the recession of the 1990 s, active life expectancy grew by 0.3 years.

Figure 2. Active, retirement and total life expectancy at birth, 1970-1993 (both sexes).

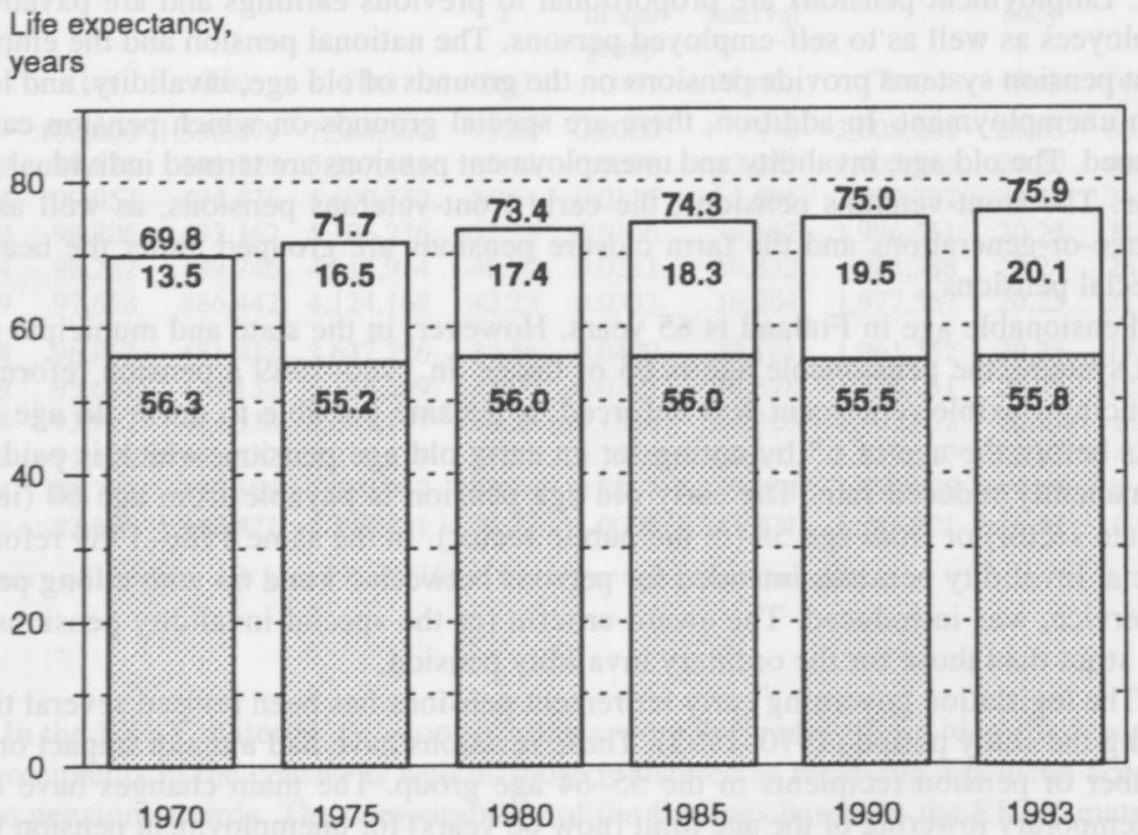

\section{Active life expectancy (eax)}

Retirement life expectancy (erx)

No major gender differences can be seen in the degree to which the increase in lifetime has occurred in the retirement years vs. the active years. In 1993 female active life expectancy was slightly less than a year shorter than in the early 1970s. In men, no appreciable change can be observed. Retirement life expectancy has increased by 6.7 years in women and by 6.3 years in men. In 1993, the female life span was on average seven years longer than the male life span; two years of that fell on the active years. (Figure 3.)

The relatively minor changes in active life expectancy may seem to conflict with the generally held assumption that average age at pension has consistently decreased. This can be attributed to the combined effect of age-specific mortality and changes in the share of pensioner population, and can be further illustrated by means of survival curves. Figure 4 shows two survival curves, the upper representing the number of surviving cohort members, by one-year age group, in the original synthetic birth cohort of 100,000 , the lower the number of cohort members who reached a particular age while not yet on a pension. The area above the surviving members of the cohort shows the proportion of members who had died by a particular age and the area between the lines the proportion of retired cohort members (see Valkonen 1986; Manton 1990; Sihvonen, Valkonen and Lahelma 1994). 
Fi g u r e 3. Active, retirement and total life expectancies by sex 1970 and 1993.

Life expectancy,

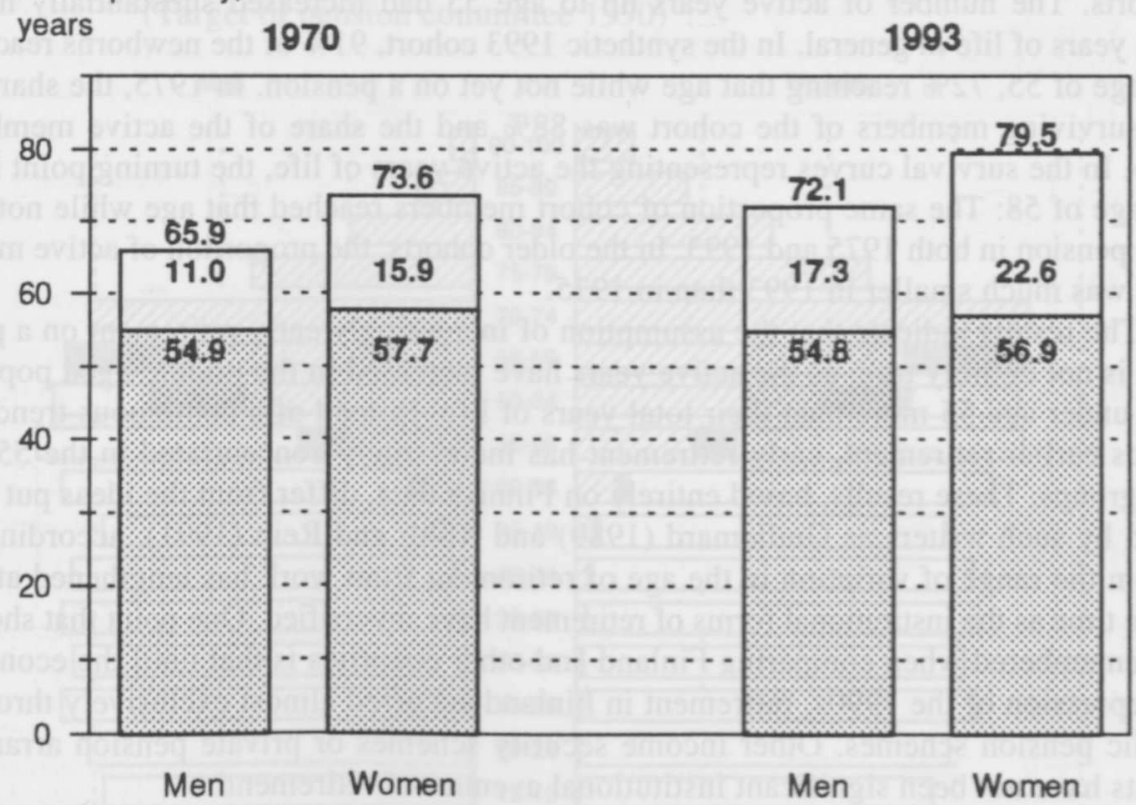

Active life expectancy (eax)

$\square$ Retirement life expectancy (erx)

Fig u r e 4. Individuals alive at age $\mathrm{x}$ and corresponding share of actives in a synthetic cohort of 100,000 live births, 1975 and 1993.

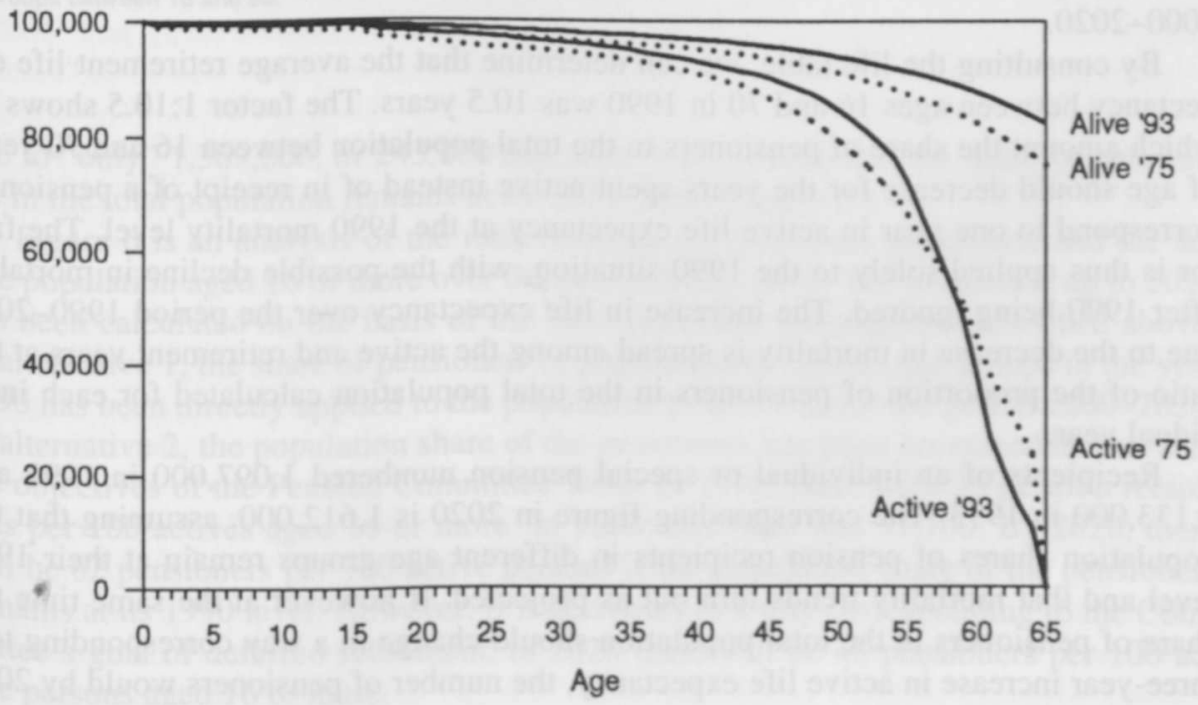


Figure 4 shows that the relatively minor changes in active life expectancy over the period 1975-1993 are explained by counteractive tendencies in the middle-aged cohorts. The number of active years up to age 55 had increased substantially more than years of life in general. In the synthetic 1993 cohort, $91 \%$ of the newborns reached the age of $55,72 \%$ reaching that age while not yet on a pension. In 1975, the share of the surviving members of the cohort was $88 \%$ and the share of the active members $67 \%$. In the survival curves representing the active years of life, the turning point is at the age of 58: The same proportion of cohort members reached that age while not yet on a pension in both 1975 and 1993. In the older cohorts, the proportion of active members was much smaller in 1993 than in 1975.

The results indicate that the assumption of increasingly early retirement on a pension is not entirely true, as the active years have increased in the middle-aged population under age 55 more than their total years of life. Instead of a continuous trend towards earlier retirement, early retirement has increasingly concentrated in the 55-64 age groups. These results, based entirely on Finnish data, differ from the ideas put forward by such writers as Guillemard (1989) and Kohli and Rein (1991), according to whom the range of variation in the age of retirement from work has lengthened at the same time as the institutional forms of retirement have diversified. One point that should be remembered when comparing Finland and other countries is that until the economic depression of the 1990 s, retirement in Finland occurred almost exclusively through public pension schemes. Other income security schemes or private pension arrangements have not been significant institutional avenues of retirement.

\section{Pension recipients in relation to the active population, 1970-2020}

One of the proposals of the Pension Committee 1990 was that measures should be taken to raise the average age at pension by one year per decennium until 2020. When applying the Committee's recommendations to active life expectancy, we must first decide which age groups can be expected to be affected by a reduction in retirement life expectancy. The least complicated alternative is to perform a calculation where retirement life expectancies are assumed to decrease by a uniform amount in all age groups between specified ages. In the following, we shall assume that the change will affect all age groups between ages 16 and 69 nearly equally and that $100 \%$ of those aged 70 or over will be receiving a pension at any point during the period 2000-2020.

By consulting the life table, we can determine that the average retirement life expectancy between ages 16 and 70 in 1990 was 10.5 years. The factor $1: 10.5$ shows by which amount the share of pensioners in the total population between 16 and 70 years of age should decrease for the years spent active instead of in receipt of a pension to correspond to one year in active life expectancy at the 1990 mortality level. The factor is thus applied solely to the 1990 situation, with the possible decline in mortality after 1990 being ignored. The increase in life expectancy over the period 1990-2020 due to the decrease in mortality is spread among the active and retirement years at the ratio of the proportion of pensioners in the total population calculated for each individual year.

Recipients of an individual or special pension numbered 1,097,000 in 1990 and $1,133,000$ in 1993. The corresponding figure in 2020 is $1,612,000$, assuming that the population shares of pension recipients in different age groups remain at their 1990 level and that mortality trends turn out as projected. If however at the same time the share of pensioners in the total population should change in a way corresponding to a three-year increase in active life expectancy, the number of pensioners would by 2020 
Fig u re 5. Active and pensioner populations in the year 2020: Impact of lengthening of active life expectancy at birth by three years in relation to 1990 . $\left(\right.$ Target of pension committee 1990) ${ }^{1)}$.
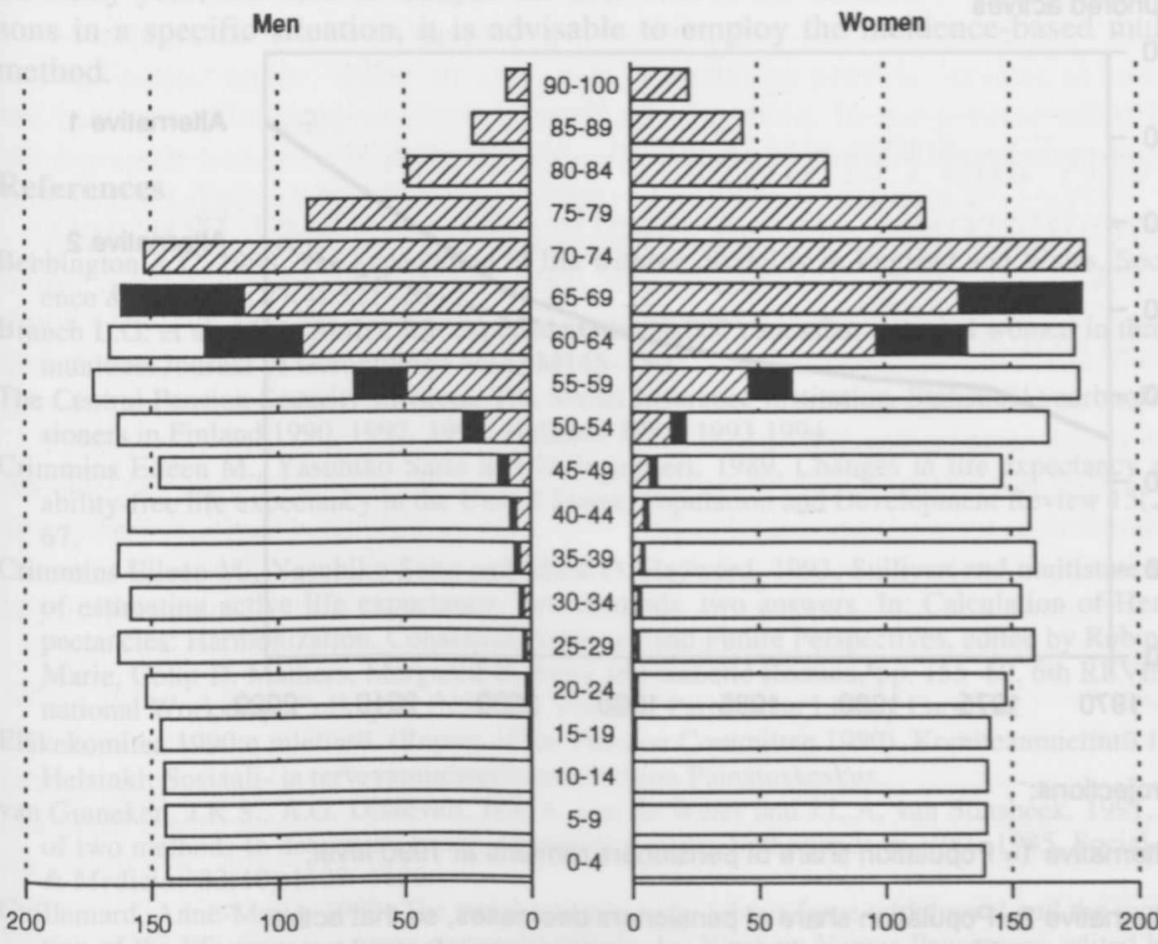

$\square$ Active population if the share of pensioners remains at the 1990 level

Decrease of pensioners population increase of active population given that active life expectancy increases by 3 years

Q Pensioner population given that active life expectancy at birth increases by 3 years

\footnotetext{
1) The population share of pension recipients in each one-year age group has been reduced in relation to 1990 so that person years moved from retirement years to active years account for three years in active life expectancy at birth at 1990 mortality level. The reduction has been made proportionally at the same rate for all one-year age groups between 16 and 69 .
}

rise to "only" $1,369,000$, or 243,000 less than if we assume that the share of pensioners in the total population remains at its 1990 level. (Figure 5.)

Figure 6 is an analysis of the ratio between the pensioner population and the active population aged 16 or more over the period $1970-2020$. The projection up to 2020 has been calculated on the basis of the two alternative assumptions described above. In alternative 1, the share of pensioners of population in various age groups in the year 1990 has been directly applied to the population projections for the period 2000-2020. In alternative 2 , the population share of the pensioners has been decreased in line with the objectives of the Pension Committee 1990. In 1970, there were 25 pension recipients per 100 actives aged 16 or more. In 1990, this ratio was 37:100. By 2020, there will be 62 pensioners per 100 active persons if the population share of the pensioners remains at its 1990 level. However, if it decreases in a way corresponding to the Committee's goal of deferred retirement, in 2020 there will be 48 pensioners per $100 \mathrm{ac}-$ tive persons aged 16 or more. 
Figure 6. Number of pension recipients relative to population aged 16 and over. Development 1970-1990 and two alternative projections 2000-2020.

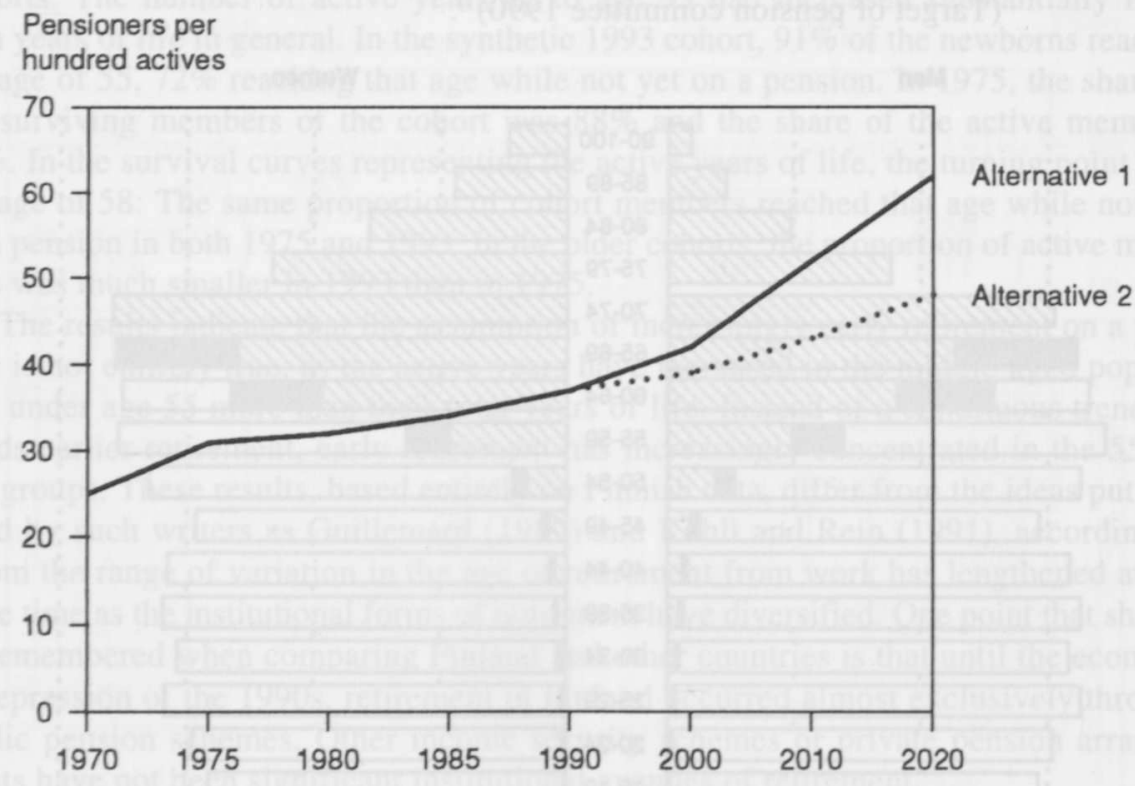

Projections:

Alternative $1=$ Population share of pensioners remains at 1990 level.

Alternative $2=$ Population share of pensioners decreases, so that active life expectancy lengthens by one year per decennium. (Change rates have been calculated at 1990 mortality rate.)

\section{Evaluation of methodology and results}

The central finding of this study is that the increase in life expectancy seen over the period 1970-1993 has almost exclusively lengthened the time spent in retirement. The active life expectancy at birth varied relatively little over the study period. The small magnitude of the changes in active life expectancy is partly due to the contradictory trends in the middle-aged population. While the number of years the population under age 55 can expect to remain free of disability has increased, there has been a trend to increasingly early retirement among the 55-64 year olds. In part, the stability of active life expectancy is built into the method applied in this study, which describes an average Finnish life span on the basis of mortality data and structural data on retirement. The population shares of pensioners are the result of pension events having occurred over a long period of time, which means that changes in active life expectancy are necessarily slow as well. Retirement life expectancy changes more quickly than active life expectancy, as decrease in mortality to a large degree affects the number of years spent on old-age pension.

A prevalence-based Sullivan method, utilizing data on demographic structures, describes the relations between active and retirement lifetimes in an actual population. It is therefore an appropriate measure when the object is to see how pension policy decisions - or overall societal trends - influence the relation between active and retirement lifetimes within a human life span. Another advantage of the method is that 
the results it provides are easily applicable to dependency ratio analyses based on the age distribution of the population. On the other hand, it does not reflect the likelihood of pension events in any particular year. If, on the basis of risk figures from a particular study year, we wish to analyze the active and retirement life expectancies of persons in a specific situation, it is advisable to employ the incidence-based multistate method.

\section{References}

Bebbington A C. 1988. The expectation of life without disability in England and Wales. Social Science \& Medicine 27(4):321-26.

Branch L.G. et al. 1991. Active life expectancy for 10,000 caucasian men and women in three communities. Journal of Gerontology 46(4):M145-150.

The Central Pension Security Institute, The Social Insurance Institution. Statistical yearbook of pensioners in Finland 1990, 1992, 1993. Helsinki 1991, 19931994.

Crimmins Eileen M., Yasuhiko Saito and D. Ingegneri. 1989. Changes in life expectancy and disability-free life expectancy in the United States. Population and Development Review 15(2): 23567.

Crimmins Eileen M., Yasuhiko Saito and Mark D. Hayward. 1993. Sullivan and multistate methods of estimating active life expectancy: two methods, two answers. In: Calculation of Health Expectancies: Harmonization, Consensus Achieved and Future Perspectives, edited by Robine, JeanMarie, Colin D. Mathers, Margared R. Bone and Isabelle Romieu, pp. 155-60. 6th REVES International Workshop, Colloques INSERM Vol.226. Paris: John Libbey Eurotext.

Eläkekomitea 1990:n mietintö. (Report of the Pension Committee 1990). Komiteanmietintö 1991:41. Helsinki: Sosiaali- ja terveysministeriö and Valtion Painatuskeskus.

van Ginneken, J.K.S., A.G. Dissevelt, H.P.A. van de Water and J.L.A. van Sonsbeek. 1991. Results of two methods to determine health expentancy in the Netherlands in 1981-1985. Social Science \& Medicine 32(10):1129-1136.

Guillemard, Anne-Marie. 1989. The trend towards early labour force withdrawal and the reorganisation of the life course: a cross-national analysis. In: Workers Versus Pensioners, edited by Johnson, P., C. Conrad and D. Thomson, pp. 163-80. Manchester: Manchester University Press.

Hytti, Helka. 1993. Työkyvyttömyyseläkkeelle siirtymisen yhteiskunnalliset taustatekijät. (Social and societal determinants of disability pension incidence). Kansaneläkelaitoksen julkaisuja M:87. Helsinki: Kansaneläkelaitos.

- 1995. Elinajantaulun monitilamallin soveltaminen eläke- ja aktiiviajan odotteisiin. (Application of the multistate method to the calculation of active and retirement life expectancies.) Kansaneläkelaitoksen tilastokatsaus 1995(1):1-6.

Kohli Martin and Martin Rein. 1991. The changing balance of work and retirement. In: Time for Retirement. Comparative Studies of Early Exit from Labor Force, edited by Kohli, Martin, Martin Rein, Anne-Marie Guillemard and Herman van Gunsteren. Cambridge: Cambridge University Press.

Manton, Kenneth. 1990. Mortality and morbidity. In: Handbook of Aging and the Social Science, edited by Binstock, Robert H. and Linda K. George. 3rd ed. San Diego: Academic Press.

Rogers, Andrei, Richard G. Rogers and A. Belanger. 1990. Longer life but worse health? Measurement and dynamics. The Gerontologist 30:640-649.

Sihvonen, Ari-Pekka. 1994. Suomalaisten toimintakykyiset elinvuodet. Metodinen tarkastelu ja mittaaminen. (Disability-free life expectancy in Finland. Methodology and measurement.) STAKES raportteja nro 148. Helsinki: STAKES.

Sihvonen, Ari-Pekka, Tapani Valkonen and Eero Lahelma. 1994. Miesten ja naisten toimintakykyiset elinvuodet Suomessa 1986. (Disability-free life expectancy by gender in Finland 1986.) Sosiaalilääketieteellinen aikakauslehti 31: 326-340.

Social tryghed i de nordiske lande 1993. (Social security in the Nordic countries.) Kobenhavn: Nordisk Socialstatistisk Komite 1995:1.

Valkonen, Tapani. 1986. Kuolleisuuden ja ikärakenteen kehitysnäkymät. (Future trends in mortality and population age structure.) In: Tutkimus ja kansanterveys: suuntauksia 1980-luvulla. Osa 2, edited by Heinonen, Olli P., Arpo Aromaa, Eino Heikkinen, Timo Klaukka, Matti Rimpelä, Jouko Tuomisto and Tellervo Raijas, pp. 11-27. Kansaneläkelaitoksen julkaisuja M:58. Helsinki: Kafisaneläkelaitos.

Valkonen, Tapani, Ari-Pekka Sihvonen and Eero Lahelma. Disability-free life expectancy by level of education in Finland. Paper prepared for the 7th REVES International Meeting, Canberra, Australia 25-25, February 1994. 